\title{
BUILDINGS' DAMAGE AT HOREMI VILLAGE, ARKADIA, GREECE: EVALUATION OF THE GEOTECHNICAL CONDITIONS AT SHALLOW DEPTHS
}

\author{
Kynigalaki M., Kanaris D., Nikolaou N., Kontogianni V. \\ IGME / Engineering Geology Dpt., Entrance C, 1, Sp. Louis St, Olympic Village, 13677 Acharnae, Athens, \\ Greece,nikolaou@igme.gr
}

\begin{abstract}
Horemi village is located in Central Peloponnesus, at the western margins of Megalopoli basin. For several years failure phenomena on the village buildings have been reported, causing problems related both to the safety of the inhabitants, as well as to the development of the area.

For the above reasons a geotechnical investigation program was carried out, to study the origin of the failures and lead to certain conclusions for the mitigation of the phenomena.

In situ exploratory works, with reference to the investigation of litho-stratigraphy, ground foundation conditions, as well as laboratory testing, provided the necessary data for further research testing of the soil physical and mechanical parameters.

Building failure recording, trial pits description, sample collection and laboratory testing, pointed out that failure phenomena are due to geotechnical rather than geological effects.

The detection of a clayey horizon, presenting high to very high plasticity and swelling behavior, related to the significant montmorillonite proportion in the surface or shallow geological formations, showed good correlation to building damages. The aforementioned observations are considered to clarify the case presented in this paper.
\end{abstract}

Key words: swelling, montmorillonite, damage on buildings, Horemi, Greece

\section{Introduction}

Damage of common buildings founded on sediments, resting by the margins of Post-alpine basins, occurs frequently in the Greek territory. This leads to long-lasting problems, social rather than technical, related to citizens' and property's safety, finally affecting the urban development.

The specific location of these areas, in terms of morphological characteristics, lithological setting, geodynamic regime, hydrogeological conditions, particular geotechnical properties and construction details of the buildings, should be studied in order to evaluate the significance of each factor to the damage observed.

Nevertheless, various other causes (human activity etc), could be involved in buildings' damage and must be encountered according to the in situ evidence.

The present paper is a contribution to cases, where local geotechnical conditions, is believed to rule the phenomena, while tectonics play also a role. This is judged to occur, due to lack of any field data, indicating broader movement effects. 
Thus this study focuses on the examination of the geotechnical behavior of the soil formations, bearing the constructions.

\section{The study area}

\subsection{Location and morphology}

Horemi village is situated, at roughly $5 \mathrm{~km}$ straight line distance, SW of Megalopolis town in central Peloponnesus (Fig.1). It is found at the western margins of Megalopolis basin at an approximate mean altitude of 380 metres. The basin is surrounded by four mountains, namely Mainalo to the north, Lykaio to the west, Taygetos to the south, Parnonas to the east and occupies the western part, of the in between the aforementioned mountains, formed low area.

At this section of the basin's margins, westwards to Alfios river, low hills are observed, separated to each other by streams. The streams present a SW to NE direction of flow and create ravines of various depths and almost vertical slopes. This low relief configuration, is related to the low, generally, dips of the geological formations and the predominance of soft horizons, in the geological structure.

The residential area of Horemi (Fig.1, is developed, at the top, almost flat part of the hill, while slopes with generally smooth morphological dips $\left(5-10^{\circ}\right)$, are formed mainly at the eastern section. Locally only, medium dipping slopes are observed.

Regarding the hydrographical network, Megalopolis basin is drained by Alfios river, his tributary Elissonas and several streams. The position of Alfios river is asymmetrical as for the long axis of the basin and this axis coincides with the general flow direction of the river that is from the SSE to the NNW. Alfios enters the basin at the south-eastern part of the basin, at an altitude of 410 metres, and further on, joins Koutifarina stream. It exits the basin of Megalopolis at the north-western edge, near Karitaina village at an altitude of 350 metres. Westwards from Koutifarina, Xerilas stream enters the basin following the SE to NW fault zone direction of Falaisia (Taygetos) region.

\subsection{Geological structure - lithological composition}

Megalopolis basin is a tectonic graben, with long axis having an approximate length of $15 \mathrm{~km}$ and direction from NNW to SSE, whereas short axis presenting a length of about $10 \mathrm{~km}$. The basin is occupied by Pleistocene formations, of lacustrine and fluvial origin. Neogene sediments outcrop mainly at the eastern margins of the basin and at places in the northern, while the basin's borders are occupied by the Alpine formations of Pindos Zone, Tripolis Zone and the Phyllite - Quartzite series, which is tectonically underlying Tripolis Zone and / or Pindos Zone.

More specifically in the north-eastern, eastern and southern sections of the basin, geological formations of Tripolis Zone prevail, while limestone tectonic segments of Pindos Zone and parts of the Phyllite - Quartzite series appear at places. Furthermore, on the western and north-western boundaries of the basin, layers of Pindos Zone are present.

Below are given, the horizons that constitute the abovementioned geotectonical Zones, according to the Geological Map of IGME of 1:50.000 scale ("Megalopolis" sheet, Papadopoulos et al., 1997). The formations are listed from the oldest to the newest and are as follows:

- Phyllite - Quartzite series

- Tripolis Zone carbonate sediments and flysch.

- Pindos Zone tectonized materials, members of the ophiolithic series, cherts, first flysch, limestones and flysch transition beds. 


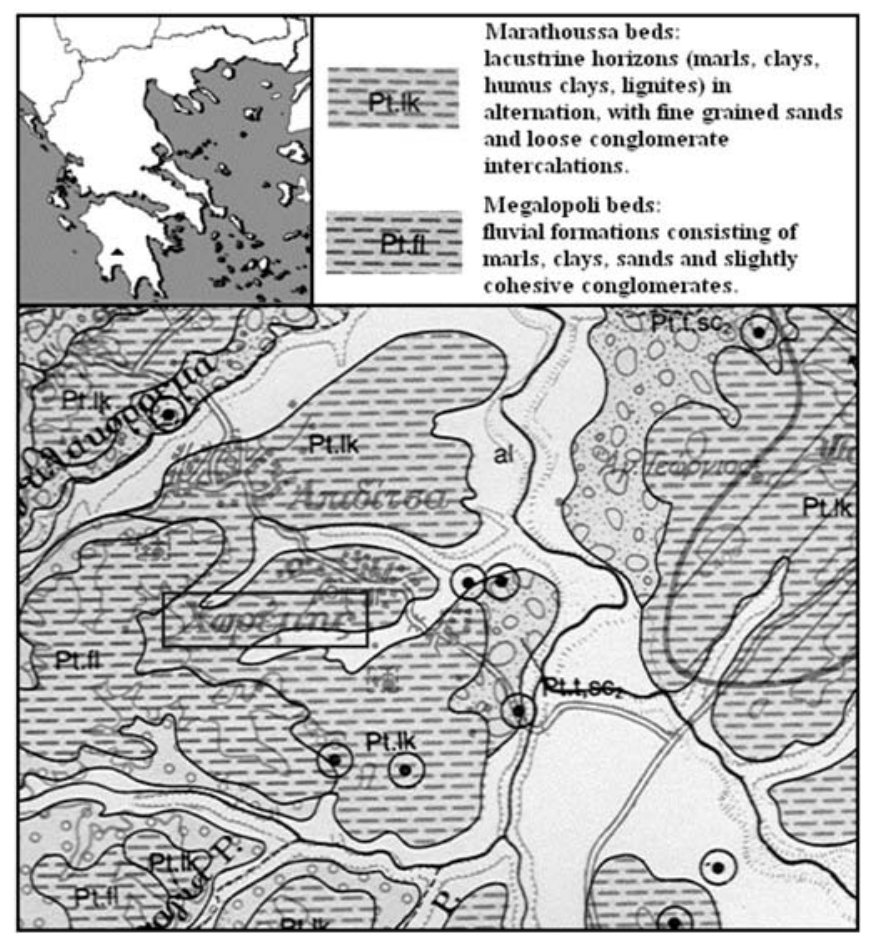

Fig. 1: Geological Map of Horemi ("Megalopolis" sheet, 1:50.000 scale, I.G.M.E., 1997). Inset: Map of Greece, triangle indicates the Horemi area.

As regards the Post-alpine formations, sediments of Pliocene, Pleistocene as well as Holocene deposits can be encountered. Analytically:

Pliocene formations: Two units of lacustrine as well as fluvial phases are met, with total thickness 60 to $120 \mathrm{~m}$, namely from base to top:

Makryssion formation: marls, clays with lignites and conglomerates.

Trilofo formation: marls, clays, loose conglomerates

\section{Pleistocene sediments:}

Apiditsa formation: terrestrial phases, consisting of red clayey sands with slightly cohesive conglomerates and scree with red clays. Thickness 50 to $100 \mathrm{~m}$.

Horemi formation: sediments of lacustrine and fluvial phases, deposited during hot and cold period of Pleistocene, respectively. They have total thickness of $200 \mathrm{~m}$ and include the following:

- Marathoussa beds: lacustrine horizons (marls, clays, lignites) in alternation, with fine grained sands and loose conglomerate intercalations (Fig.1).

- Megalopoli beds: fluvial formations consisting of marls, clays, sands and slightly cohesive conglomerates laterally passing to Marathoussa beds (Fig.1).

Thoknia-Potamia formation: they constitute the two basin's terraces and consist of silts, clays, sands, gravel, loose conglomerates and mixed phases in the form of scree. Total thickness of 10 to $40 \mathrm{~m}$.

\section{Holocene deposits:}

Recent and old talus cones and scree: silts, loam and loose conglomerates.

Alluvial deposits: Loose clayey-sands with gravel and cobbles in the river and stream beds, as well as terraces of small extent. 
Referring to the strict Horemi village area, according to the Geological Map of Figure 1, the urban area is founded on the Pleistocene aged Horemi formation and to be exact in Marathoussa beds.

\subsection{Geodynamic regime}

\subsubsection{Tectonics}

Megalopolis basin was created as a tectonic graben, between Oligocene and Upper Pliocene age. It was formed after the overthrust movement of Pindos Zone over Tripolis Zone, during the en echelon faulting phase that followed.

The basin was initially filled with lacustrine sediments, while deposition of lacustrine, and river materials in alternations, followed. This was the result of the continuing sinking of the basin, the uplift of its margins, the circles of erosion and deposition, as well as of the alternation of hot and cold periods. It is also related to the speed of rise of the water level in the interior of the basin. The continual sinking of Megalopolis basin and uplift of its marginal zones, is connected to the earthquake potential of the region.

Regarding the structure of the Alpine basement, at the marginal zone and at the interior of Megalopolis basin also, geophysical researches (Papadopoulos, 1985) showed the following: starting from the eastern part of the basin, the basement gradually passes from higher to deeper horizons until Perivolia village to the west. Afterwards it falls abruptly to the west, up to a depth of about $500 \mathrm{~m}$. In the western part of the basin, the basement falls rapidly to the east and sketches out a fault zone, with direction NW/SE, almost parallel to the flow of Alfios river. This fault zone along the west margins of the basin is crossed by E-W directing faults. Finally in the central part of the basin, no features of particular tectonic interest are observed.

\subsubsection{Seismicity}

The region of Central Peloponnesus presents intense seismic activity since the antiquity (Galanopoulos, 1955). Earthquakes which occurred during the historical years and are reported as catastrophic for the region of Megalopolis, are the following:

-1783 , earthquake felt in Gortynia region caused failure in churches, as well as collapse of houses in Stemnitsa village.

-1897 and 1898 two earthquakes sensed in all Southern Greece and Italy caused damage in Tripoli.

Afterwards, during the modern period, the following earthquakes are characterized as the most disastrous for the region of Megalopolis:

- 1952, 13 June, a strong earthquake caused damage in Horemi.

- 1965, 5 April, a severe earthquake occurred in Central Peloponnesus and caused deaths and injuries, created ground failure and destroyed completely 1.426 houses. Among the most damaged villages are Horemi, Apiditsa, and Tripotamo (intensity X Mercalli).

- 1966, 1 September, a disastrous earthquake took place in the region of Megalopolis, where injuries and building collapses were recorded (intensities VII-VIII Mercalli). The most serious building damages were well correlated with the foundation conditions, morphology and tectonics of the site.

In the bibliography (Papadopoulos, 1985), is pointed out that the seismic activity of Megalopolis basin seems to be mainly expressed at the margins, along or near tectonic lines, with directions NNW-SSE and E-W respectively. 
Also in conclusion, the above researcher marks out that high seismic intensities in the basin of Megalopolis, are owed mainly to the physical and mechanical properties of the Pleistocene formations, as well as to the geometry of the geological basement. Thus, despite the significant thickness of these sediments (up to $500 \mathrm{~m}$ ) at the western margin, the severe destructions caused by the earthquakes are related to the intense slope of the geological basement, as a result of faulting.

\section{Site investigation}

For the needs of the present research, in Horemi village, one (1) geotechnical borehole, up to 40.50m in depth and in situ testing (SPT, permeability) have been carried out, while seven (7) trial pits have also been excavated. According to the $(\mathrm{N})$ value of blows, the fine grained soils met are characterized as stiff and the coarse grained as dense. In addition, the permeability of the formations, was found to be low, in general.

\section{Laboratory testing}

Soil mechanics laboratory tests (Soil Mechanics Lab of IGME) were implemented in selected samples, for the measurement of their physical and mechanical parameters. Also, mineralogical studies (Dept. of Mineralogy and Petrology, IGME), for the quantitative and qualitative determination of their mineralogical composition, were also conducted. Below, the results of the as above laboratory analyses are specified:

\subsection{Soil mechanics}

Fifteen samples, chosen from the borehole cores, as well as the trial pits' materials, were tested, for the determination of their grain size distribution, consolidation, shear strength and unconfined compression strength parameters.

In the samples taken from the shallow horizons, the existence of a fractured, stiff clay, was found out. It presents high to very high plasticity, smooth slikenslide surfaces covered by Mn oxides, mean thickness of $2.00 \mathrm{~m}$ and was observed in a depth varying from $0.40 \mathrm{~m}$ to $3.60 \mathrm{~m}$. The swelling pressure measured, ranges from 50 up to $400 \mathrm{kPa}$.

\subsection{Mineralogical studies}

Given that the clayey formations met during the investigations at Horemi, present expansion, four samples from the borehole drilled and three samples from the trial pits, were chosen for mineralogical analyses. These analyses revealed high percentages of quartz and ( $\mathrm{Na}, \mathrm{Ca}$ ) montmorillonite in all the samples examined, as well as absence of calcite in the mineralogical composition of the samples taken from the trial pits.

Montmorillonite belongs to smectites, which constitute one of the chief swelling clay minerals group, while Na-montmorillonite presents the greatest potential for expansion, of all the clay minerals. It forms crystals very small in size, characterized by intense moisture uptake (Gillot, 1987).

\section{Geotechnical evaluation}

The activity of clays has a direct relationship with plasticity index and clay fraction of whole sample $(\%<2 \mu \mathrm{m})$. Activity ranges between 0.50 and 0.80 for all samples corresponding to normal clays, with only one sample being no active (activity 0.20 ). 


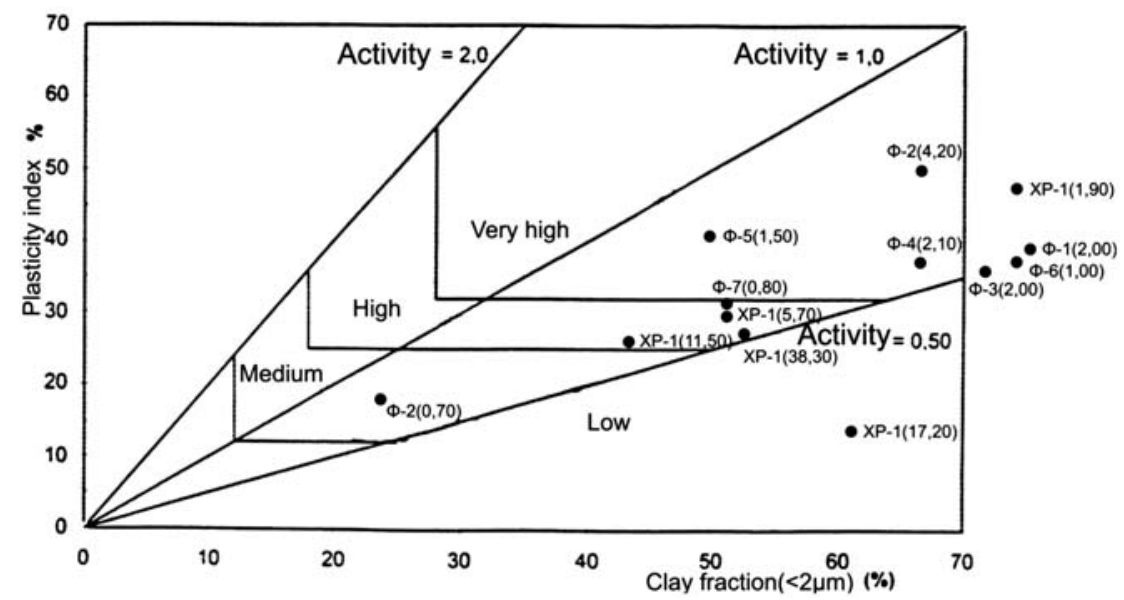

Fig. 2: Activity and swell potential of examined soils, Van der Merwe (1964) modified by Grabowska Olszewska (1998).

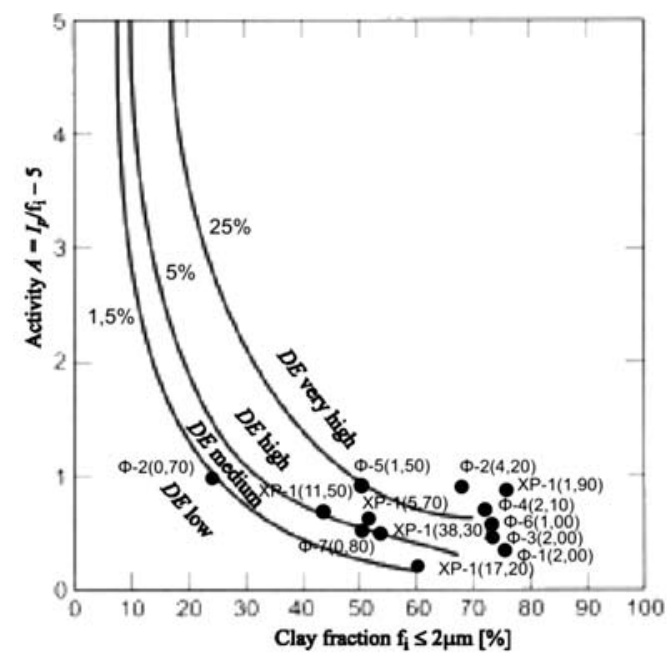

Fig. 3: Degree of expansion (DE) classification chart according to Seed et al. (1962).

Concerning the swell seven samples have very high, five samples high - medium and one sample low swell potential (Van der Merwe, 1964, chart modified by Grabowska - Olszewska 1998 for the evaluation of potential expansiveness, Fig.2).

For quantitative evaluation of the swell according to Seed et al (1962) it was estimated that five (5) samples have very high (>25\%), six (6) samples have high (5-25\%) and only two (2) samples have low degree of expansion (1.5\%, Fig.3).

\section{Buildings' failure assessment.}

Three in situ investigations at Horemi village between May 2007 and April 2008 aimed to record damage on buildings and other structures. Recorded damage involved fractures on the walls of several houses and yards located at areas indicated on the map of figure 4. All fractures share the following characteristics: they are either diagonal, breaking the house walls (Fig.5), or horizontal and 


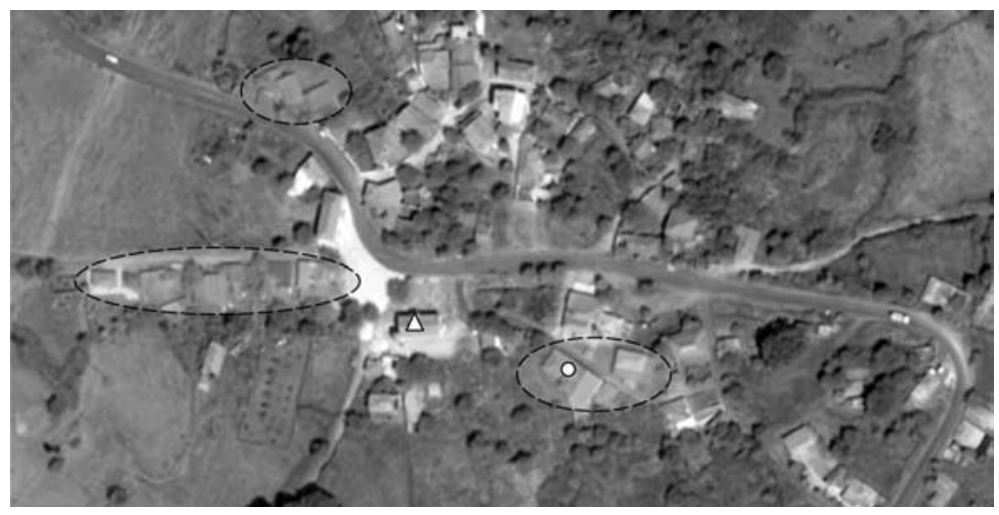

Fig. 4: Aerial photo of Horemi village. Areas with damaged buildings are drawn. The dot indicates the house with most important damage and the triangle indicates the church of Horemi (see also Fig. 5).
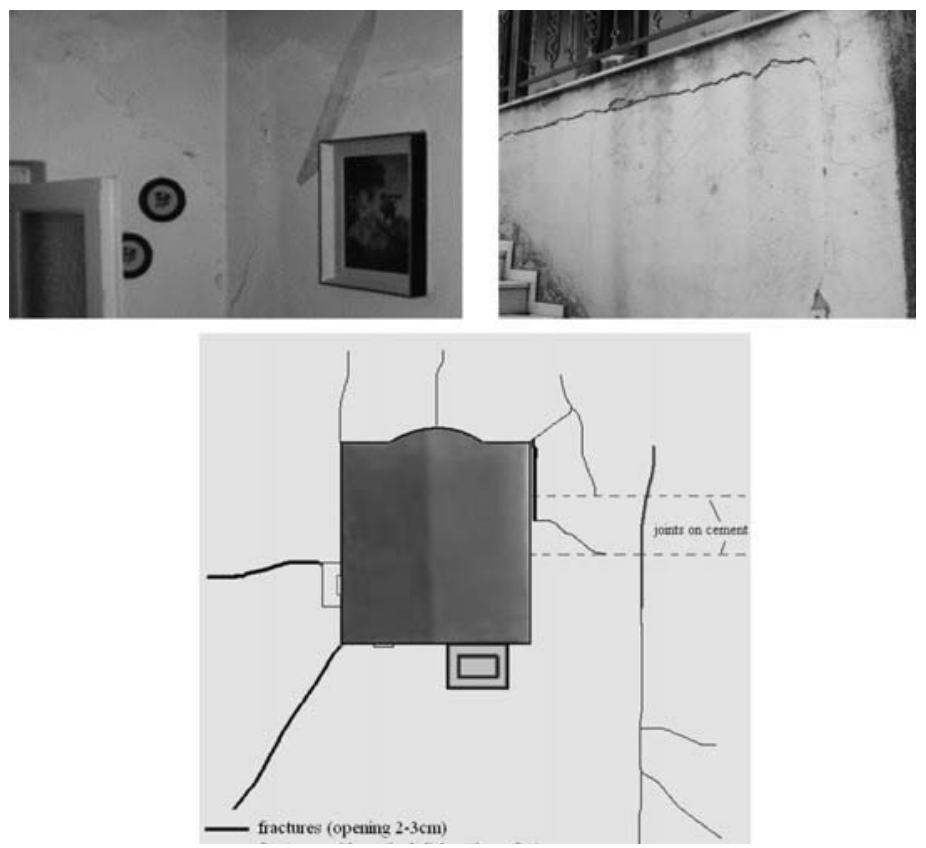

Fig. 5: Top: Photos from the house with most important damage (dot on map of Fig. 4), showing extensive fractures (diagonal, vertical and horizontal) on the walls. Bottom: A sketch showing allocation of fractures on the cement yard of the church (triangle on map of Fig. 4).

vertical unjoining the walls from the structure skeleton (Fig.5). Both types of fractures reveal shear stresses due to differential settlement of the building.

Besides damage on buildings, extensive failure was found at cement yards, as for instance around the church of the village (Fig.5). Those fractures, locally showing vertical dislocation, are obviously due to ground settlement. 


\section{Discussion}

Laboratory tests revealed that clays at Horemi undergo significant swelling when water content increases. Inevitably, when water is removed, i.e. due to seasonal changes of the ground water, shrinking phenomena take place. Swelling and shrinking occur at successive circles generating small fractures in the clay and locally, at relatively higher loadings - for instance beneath two-store buildings as shown above (Fig. 5) - sliding along these fractures is triggered. This seems to be the most likely reason for damage observed at heavier, though newer, houses founded on the clay.

The mechanism of swelling and shrinkage seems to be responsible also for detachment and breaking of cement yards around the church (Fig. 5) and houses at Horemi village.

\section{Conclusions}

Horemi village is founded on Pleistocene aged lacustrine, thick formations, situated at the western part of Megalopolis basin, where the geological basement falls rapidly to the east, as a result of the NW/SE fault zone, crossed by E-W directing faults. The seismic history of the area, mainly expressed at the margins of the basin, is characterized by high seismic intensities due to the physical and mechanical properties of the Pleistocene formations, as well as to tectonics.

Site investigation and lab testing revealed, at shallow depths, the existence of a fractured, stiff clay, presenting high to very high plasticity. Slikenslide surfaces were observed while a significant high percentage of montmorillonite was determined. Thus, high swelling potential and degree of expansion were detected.

The above engineering geological characteristics, in relation to the mineralogical composition, seem to indicate the mechanism causing the buildings' damage: swelling and shrinking successive circles, generating small fractures in the clay and locally sliding along these fractures.

\section{References}

Carter, M. 1983. Geotechnical Engineering Handbook. London, 226pp.

Gillot, J. 1987. Clay in Engineering Geology. Amsterdam, Elsevier Publications.

Kaperonis, N., Athanassiou, A., Agelopoulos, G., 1974. Geological research of "Marathousa - Northern Horemi" lignite-bearing field of Megalopolis Basin. Athens, Public Power Corporation Publications.

Papadopoulos, P., Luettig, G., Vinken, R. 1997. Geological Map, scale 1:50.000, “Megalopolis” sheet, Athens (IGME).

Papadopoulos, T., 1985. Geophysical researches in the region of Megalopolis Basin. PhD Thesis. Athens, Univercity Publications.

Papazachos, V., Papazachou, K., 1989. The earthquakes of Greece. Thessaloniki, Ziti Publications.

Spyropoulos P., 1997. Chronicle of earthquakes in Greece, from the antiquity up to today. Athens - Giannena, Dodoni Publications.

Tzitziras. A., 2001. Geotechnical reconnaissance in Tripotamos and Horemis villages, Municipality of Megalopolis, Athens (IGME unpublished report in greek).

Vetoulis, D., 1965. Geological report on the review of seismically affected settlements of Tripotamia Gortynias and Tripotamos Megalopolis, in Arkadia Prefecture Athens (IGEY unpublished report in greek). 